Review

\title{
Updates in the Diagnosis and Management of Linear IgA Disease: A Systematic Review
}

\author{
Leah Shin ${ }^{1}$, Jeffrey T. Gardner II ${ }^{2}$ and Harry Dao, Jr. ${ }^{2, *}$ \\ 1 Loma Linda University School of Medicine, Loma Linda, CA 92708, USA; Lshin@llu.edu \\ 2 Department of Dermatology, Loma Linda University School of Medicine, Loma Linda, CA 92708, USA; \\ JeffreyGardner@llu.edu \\ * Correspondence: Hadao@llu.edu
}

Citation: Shin, L.; Gardner, J.T., II; Dao, H., Jr. Updates in the Diagnosis and Management of Linear IgA Disease: A Systematic Review. Medicina 2021, 57, 818. https:// doi.org/10.3390/medicina57080818

Academic Editors: Sylvia Hsu and Kiran Motaparthi

Received: 10 July 2021

Accepted: 10 August 2021

Published: 12 August 2021

Publisher's Note: MDPI stays neutral with regard to jurisdictional claims in published maps and institutional affiliations.

Copyright: (c) 2021 by the authors. Licensee MDPI, Basel, Switzerland. This article is an open access article distributed under the terms and conditions of the Creative Commons Attribution (CC BY) license (https:// creativecommons.org/licenses/by/ $4.0 /)$.
Abstract: Background and Objectives: Linear IgA disease (LAD) is a rare autoimmune blistering disease with linear IgA deposits along the basement membrane zone. Direct immunofluorescence remains the gold standard for diagnosis, but other diagnostic measures reported in recent literature have proven useful in the setting of inconclusive preliminary results. Dapsone is a commonly used treatment, but many therapeutic agents have emerged in recent years. The objective of this study is to provide a comprehensive overview of updates on the diagnosis and management of LAD. Materials and Methods: A literature search was conducted from May to June of 2021 for articles published in the last 5 years that were related to the diagnosis and management of LAD. Results: False-negative results in cases of drug-induced LAD and the presence of IgG and IgM antibodies on immunofluorescence studies were reported. Serration pattern analysis has been reported to be useful in distinguishing LAD from sublamina densa-type LAD. Rituximab, omalizumab, etanercept, IVIg, sulfonamides, topical corticosteroids, and others have been used successfully in adult and pediatric patients with varying disease severity. Topical corticosteroids were preferred for pediatric patients while rituximab and IVIg were used in adults with recalcitrant LAD. Sulfonamides were utilized in places without access to dapsone. Conclusion: In cases where preliminary biopsy results are negative and clinical suspicion is high, repeat biopsy and additional diagnostic studies should be used. Patient factors such as age, medical comorbidities, and disease severity play a role in therapeutic selection.

Keywords: linear IgA bullous dermatosis; autoimmune diseases; immunoglobulin A; fluorescent antibody technique; rituximab; etanercept; omalizumab

\section{Introduction}

Linear IgA disease (LAD) is an autoimmune mucocutaneous disease characterized by linear deposits of $\operatorname{IgA}$ at the basement membrane zone on immunopathology [1]. It is also known as linear IgA bullous dermatosis (LABD), but LAD is preferred because it is inclusive of patients without bullous lesions [2]. In the pediatric population, it is known as chronic bullous disease of childhood (CBDC). Direct immunofluorescence (DIF) remains the gold standard for diagnosis in both adult and pediatric populations, but there have been cases of false-negative results in drug-induced LAD [3,4]. Management of this relatively rare disease process varies throughout the literature. Dapsone is the most commonly used therapeutic agent, but its potential side effects such as hemolysis, agranulocytosis, and methemoglobinemia necessitate the use of other treatment modalities. Monitoring for dapsone adverse reactions can be cumbersome as well. Numerous other treatments have been reported to be effective in the treatment of LAD, including topical corticosteroids, tetracyclines, dicloxacillin, oxacillin, erythromycin, sulfonamides, nicotinamide, rituximab, omalizumab, methotrexate, cyclosporine, etanercept, and intravenous immunoglobulin (IVIg) [1,5-21]. This review provides updates on the diagnosis of LAD and emerging treatment modalities in order to assess their utility in the management of this disease. 


\section{Materials and Methods}

A literature search was conducted from May to June of 2021 using the online database PubMed. To maximize results, a broad search term "linear igA" was used. Titles and summaries of articles were screened for relevance to LAD diagnosis and treatment, followed by the assessment of abstracts and full-text manuscripts. Information on the diagnosis and treatment of LAD were extracted by two independent reviewers. Only articles published between 2016 and 2021 with full-text access and updates to LAD diagnosis and management were included in this review.

\section{Results}

\subsection{Literature Search}

A preliminary search yielded 401 articles published between 2016 and 2021 that were related to "linear igA". The titles, summaries, and abstracts were screened for relevance to the topic, leaving a total of 65 articles. These studies were assessed further by reading the abstract or full text. Articles without full-text access or those that were unrelated to diagnosis or management were not retrieved. This left 30 studies that met the inclusion criteria, in addition to 2 articles recommended by peer reviewers (Figure 1).

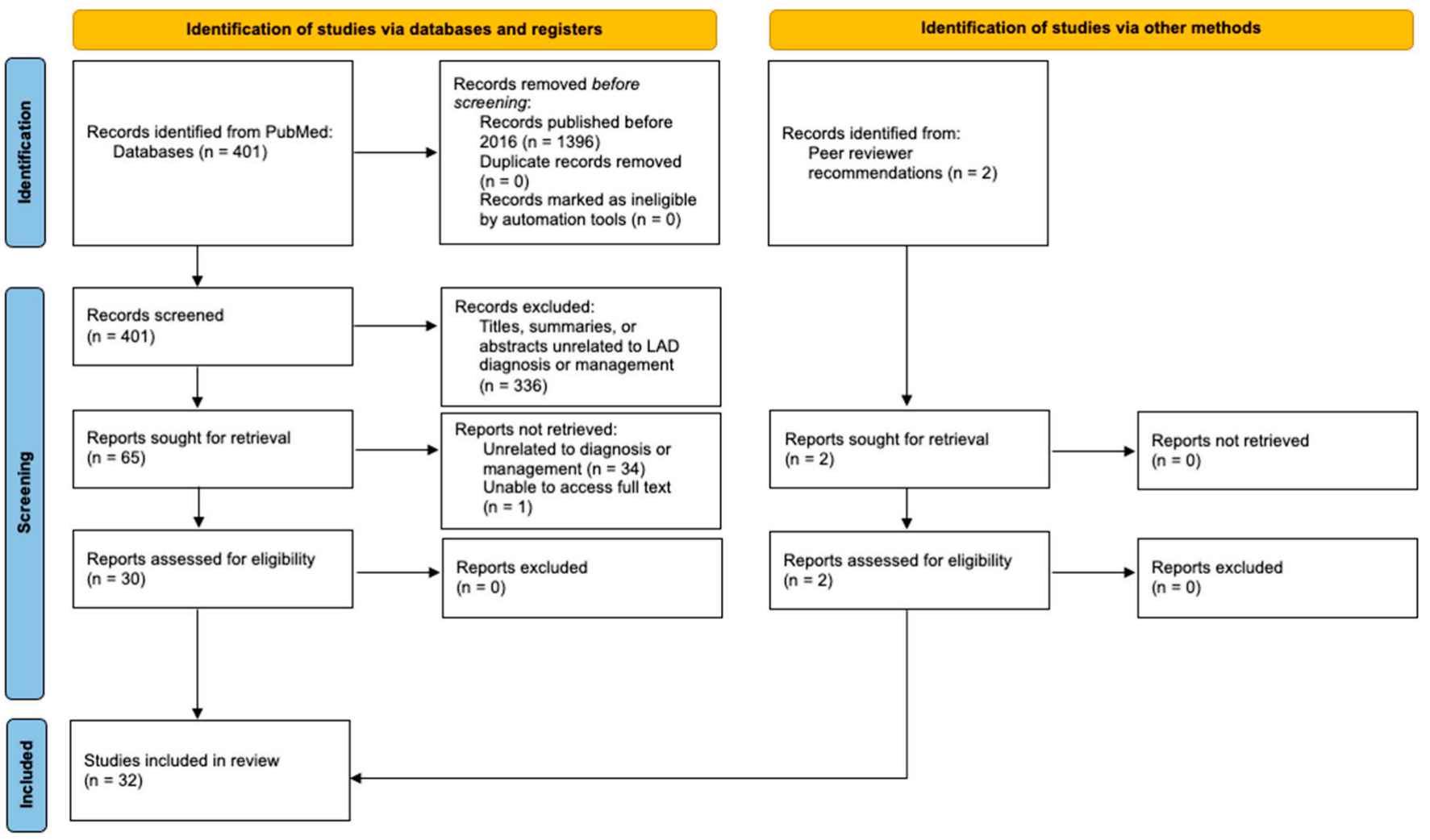

Figure 1. Flow diagram of the systematic review.

\subsection{Diagnosis}

Recent reports show that conventional diagnostic studies may not be the most accurate for drug-induced LAD. One case of vancomycin-induced LAD in a patient with renal insufficiency initially showed a negative DIF, but upon repeat biopsy, DIF result was positive [3]. This case highlights the importance of repeat DIF if clinical suspicion is high and if patients have immune dysregulation such as renal insufficiency, which can alter immunofluorescence studies. In another case of vancomycin-induced LAD, despite positive DIF results, indirect immunofluorescence (IIF) was negative unless the serum was 
co-incubated with the offending agent, vancomycin [4]. A unique flame figure formation with numerous eosinophils on hematoxylin and eosin (H\&E) has also been reported in drug-induced LAD [22].

In situations where similar conditions such as when sublamina densa-type LAD is in the differential, IIF is often used to aid in the diagnosis. Unfortunately, up to $30 \%$ of patients with LAD can have a negative IIF. If this is the case, serration pattern analysis can help distinguish between the two. LAD has an "n-serrated" pattern versus the "u-serrated" pattern of sublamina densa-type LAD [23]. It is significant to differentiate between the two because treatment response can vary depending on the diagnosis. In one study, three out of four patients with sublamina densa-type LAD did not respond well to dapsone and had to be placed on combination therapy with IVIg, doxycycline, rituximab, mycophenolate mofetil (MMF), as well as oral and topical corticosteroids [24]. One point worthy of note is the term IgA epidermolysis bullosa acquisita (EBA), which is considered arcane because it does not incorporate the immunologic or molecular qualities of the disease [2].

Though LAD is typically associated with IgA on immunofluorescence testing, there are exceptions. IgG can be seen with IgA on DIF, which some call linear IgA/IgG bullous dermatosis (LAGBD). In a pediatric patient with both IgA and IgG positivity on DIF, dapsone alone was not enough to control ocular involvement, prompting the use of oral prednisone and corticosteroid eyedrops [25]. IgM has also been seen, albeit rarely, with $\operatorname{IgA}$ and $\operatorname{IgG}$ in a linear fashion in the basement membrane zone, although IIF results were negative for $\operatorname{IgA}$ and $\operatorname{IgG}$ [26]. Another study found that around $50 \%$ of patients with LAD were positive for IgG on enzyme-linked immunosorbent assay (ELISA) or immunoblotting while being negative for linear IgG on DIF [27].

\subsection{Treatment}

In recent years, rituximab, IVIg, and others have been increasingly utilized and reported due to the adverse effects, lack of access, and treatment failure of dapsone (Table 1). These agents were often used in combination with systemic corticosteroids. There are only a few published cases that used omalizumab and etanercept, therefore data are limited on the efficacy of these agents as a treatment for LAD. In the pediatric population, management tended to be more conservative with systemic and topical corticosteroids or nicotinamide. Dosing regimens, time to clearance, and relapse rates varied throughout this literature review.

Table 1. Review of alternative therapeutic agents documented in the literature from 2016 to 2021.

\begin{tabular}{|c|c|c|c|c|c|c|}
\hline Drug & Dose & Age (Years) & $\begin{array}{l}\text { Drug-Induced } \\
\text { LAD (Y/N) }\end{array}$ & $\begin{array}{c}\text { Time to } \\
\text { Clearance } \\
\text { (yrs/m/w/d) }\end{array}$ & $\begin{array}{l}\text { Relapse } \\
(\mathrm{Y} / \mathrm{N})\end{array}$ & $\begin{array}{c}\text { Side Effects } \\
\text { of } \\
\text { Treatment }\end{array}$ \\
\hline $\begin{array}{l}\text { Rituximab + } \\
\text { prednisone }+ \\
\text { MMF [11] }\end{array}$ & $\begin{array}{c}\text { Rituximab: } 375 \mathrm{mg} / \mathrm{m}^{2} \\
\text { weekly } \times 4 \mathrm{w} \\
\text { Prednisone: } 0.5 \mathrm{mg} / \mathrm{kg}(80 \\
\text { mg) tapered over } 1 \mathrm{~m} \\
\text { MMF: } 500 \mathrm{mg}\end{array}$ & 43 & $\mathrm{~N}$ & $1 \mathrm{~m}$ & Y, 9 m later & NS \\
\hline $\begin{array}{l}\text { Rituximab }+ \\
\text { dapsone }+ \\
\quad \text { topical } \\
\text { corticosteroids } \\
+ \text { MMF [8] }\end{array}$ & $\begin{array}{c}\text { Rituximab: } 2 \text { infusions of } 1 \\
\text { g } 2 \mathrm{w} \text { apart } \times 2 \\
\text { Dapsone: unspecified } \\
\text { Topical corticosteroids: } \\
\text { unspecified } \\
\text { MMF: } 3 \mathrm{~g} / \mathrm{d} \text { to } 500 \mathrm{mg} / \mathrm{d}\end{array}$ & 35 & Unknown & $14 \mathrm{~m}$ & Y, 6 m later & NS \\
\hline $\begin{array}{c}\text { Rituximab + } \\
\text { dapsone + IVIg } \\
{[9]}\end{array}$ & $\begin{array}{l}\text { Rituximab: } 1 \mathrm{~g} \times 2 \text { cycles } \\
\text { Dapsone: } 100 \mathrm{mg} \text { to } 50 \mathrm{mg} \\
\text { IVIg: } 2 \mathrm{~g} / \mathrm{kg} / \text { cycle }\end{array}$ & 33 & $\mathrm{~N}$ & $7 w$ & $\mathrm{~N}$ & None \\
\hline
\end{tabular}


Table 1. Cont.

\begin{tabular}{|c|c|c|c|c|c|c|}
\hline Drug & Dose & Age (Years) & $\begin{array}{l}\text { Drug-Induced } \\
\text { LAD (Y/N) }\end{array}$ & $\begin{array}{c}\text { Time to } \\
\text { Clearance } \\
\text { (yrs/m/w/d) }\end{array}$ & $\begin{array}{c}\text { Relapse } \\
(\mathrm{Y} / \mathrm{N})\end{array}$ & $\begin{array}{c}\text { Side Effects } \\
\text { of } \\
\text { Treatment }\end{array}$ \\
\hline $\begin{array}{l}\text { Rituximab }+ \\
\text { dapsone }+ \\
\text { prednisone }+ \\
\text { doxycycline }+ \\
\quad \text { MMF [8] }\end{array}$ & $\begin{array}{c}\text { Rituximab: } 2 \text { infusions of } 1 \\
\text { g } 2 \mathrm{w} \text { apart } \times 2 \\
\text { Dapsone: } 200 \mathrm{mg} / \mathrm{d} \\
\text { Prednisone: } 0.1 \mathrm{mg} / \mathrm{kg} / \mathrm{d} \\
\text { Doxycycline: } 200 \mathrm{mg} / \mathrm{d} \\
\text { MMF: } 1 \mathrm{~g} / \mathrm{d}\end{array}$ & 30 & Unknown & $20 \mathrm{~m}$ & $\mathrm{~N}$ & NS \\
\hline $\begin{array}{l}\text { Rituximab + } \\
\text { IVIg [12] }\end{array}$ & $\begin{array}{l}\text { Rituximab: } 2 \text { infusions of } 1 \\
\text { g } 2 \mathrm{w} \text { apart } \\
\text { IVIg: } 2 \mathrm{~g} / \mathrm{kg} / \text { cycle divided } \\
\text { over } 3 \mathrm{~d} \times 2\end{array}$ & 21 & Unknown & $\begin{array}{l}17 \mathrm{~m} \text { follow-up } \\
\text { showed } \\
\text { improvement in } \\
\text { visual acuity } \\
\text { and less } \\
\text { conjunctival } \\
\text { cicatrization }\end{array}$ & $\mathrm{N}$ & None* \\
\hline Omalizumab & $\begin{array}{c}\text { Dose regimen } 1: \\
\text { Subcutaneous } 300 \mathrm{mg} \\
\text { every } \mathrm{m} \times 6 \mathrm{~m} \mathrm{[13]} \\
\text { Dose regimen } 2 \text { : } \\
\text { Subcutaneous } 300 \mathrm{mg} \\
\text { every } \mathrm{m} \times 3 \mathrm{~m}[14]\end{array}$ & $\begin{array}{l}55 \\
40\end{array}$ & $\begin{array}{c}\mathrm{N} \\
\text { Unknown }\end{array}$ & $\begin{array}{c}3 \mathrm{w} \\
4.5 \mathrm{~m}\end{array}$ & $\begin{array}{l}\text { Y, within } 1 \\
\text { m of } \\
\text { cessation } \\
\text { N }\end{array}$ & $\begin{array}{l}\text { NS } \\
\text { NS }\end{array}$ \\
\hline Etanercept [17] & $50 \mathrm{mg} \times 1$ & 65 & Y & $4 \mathrm{~d}$ & NS & None \\
\hline $\begin{array}{l}\text { Methotrexate + } \\
\text { mesalamine ** } \\
\text { after high dose } \\
\text { prednisone + IV } \\
\text { methylpred- } \\
\text { nisolone } \\
\text { [15] }\end{array}$ & $\begin{array}{l}\text { Methotrexate: } 22.5 \mathrm{mg} / \mathrm{w} \\
\text { Mesalamine: unspecified } \\
\text { Prednisone: unspecified } \\
\text { Methylprednisone: } 3 \mathrm{~d} \\
\text { course }\end{array}$ & 58 & $\mathrm{~N}$ & $\begin{array}{l}\text { NS, but near } \\
\text { clearance } \\
\text { achieved }\end{array}$ & NS & NS \\
\hline $\begin{array}{c}\text { Sulfasalazine } \\
{[6]}\end{array}$ & $40-60 \mathrm{mg} / \mathrm{kg}$ daily & 17 & $\mathrm{~N}$ & $2 \mathrm{~m}$ & $\mathrm{~N}$ & None \\
\hline $\begin{array}{c}\text { Sulfamethoxy } \\
\text { pyridazine [28] }\end{array}$ & $250 \mathrm{mg}-1 \mathrm{~g} / \mathrm{d}$ & 7 & $\mathrm{~N}$ & $60 \mathrm{~m}$ & $\mathrm{~N}$ & NS \\
\hline $\begin{array}{c}\text { IVIg }+ \\
\text { prednisolone } \\
{[19]}\end{array}$ & $\begin{array}{c}\text { IVIg: } 2 \mathrm{~g} / \mathrm{kg} \text { or } 0.4 \mathrm{~g} / \mathrm{kg} \\
\text { for a median of } 6 \text { doses } \\
\text { over } 2-5 \mathrm{~d}+\text { Prednisolone: } \\
5-10 \mathrm{mg} / \mathrm{d}\end{array}$ & $\begin{array}{l}\text { Unspecified, } \\
\text { range of } \\
64-84\end{array}$ & Unknown & NS & $\mathrm{N}$ & None $* * *$ \\
\hline $\begin{array}{l}\mathrm{IVIg}+ \\
\text { prednisolone } \\
{[28]}\end{array}$ & $\begin{array}{c}\text { IVIg: } 2 \mathrm{~g} / \mathrm{kg} / \text { cycle } \times 8 \\
\text { Prednisolone: } 0.5-1 \\
\mathrm{mg} / \mathrm{kg} / \mathrm{d}\end{array}$ & 13 & $\mathrm{~N}$ & $30 \mathrm{~m}$ & $\mathrm{~N}$ & NS \\
\hline IVIg [28] & $2 \mathrm{~g} / \mathrm{kg} /$ cycle $\times 8$ cycles & $9,1.7$ & $\mathrm{~N}$ & $96 \mathrm{~m}, 7 \mathrm{~m}$ & $\mathrm{~N}$ & NS \\
\hline $\begin{array}{l}\text { IVIg }+ \\
\text { prednisolone }+ \\
\text { clarithromycin } \\
{[28]}\end{array}$ & $\begin{array}{c}\text { IVIg: } 2 \mathrm{~g} / \mathrm{kg} / \mathrm{cycle} \\
\text { monthly } \times 5 \\
\text { Prednisolone: } 1 \mathrm{mg} / \mathrm{kg} / \mathrm{d} \\
\text { Clarithromycin: } 30 \\
\mathrm{mg} / \mathrm{kg} / \mathrm{d} \text { over } 3 \text { doses }\end{array}$ & 1 & $\mathrm{~N}$ & $6 \mathrm{~m}$ & $\mathrm{~N}$ & NS \\
\hline $\begin{array}{c}\text { Dapsone + } \\
\text { prednisone [29] }\end{array}$ & $\begin{array}{c}\text { Dapsone: } 50 \mathrm{mg} / \mathrm{d} \\
\text { Prednisone: } 1 \mathrm{mg} / \mathrm{kg} / \mathrm{d} \\
(60 \mathrm{mg} / \mathrm{d}) \text { tapered to } 10 \\
\mathrm{mg} / \mathrm{d}\end{array}$ & 44 & $\mathrm{~N}$ & $\begin{array}{l}\text { Clearance not } \\
\text { achieved }\end{array}$ & $\begin{array}{l}\text { Clearance } \\
\text { not } \\
\text { achieved }\end{array}$ & $\begin{array}{c}\text { Glaucoma, } \\
\text { arterial hy- } \\
\text { pertension, } \\
\text { osteoporo- } \\
\text { sis, } \\
\text { Cushingoid } \\
\text { facies }\end{array}$ \\
\hline
\end{tabular}


Table 1. Cont.

\begin{tabular}{|c|c|c|c|c|c|c|}
\hline Drug & Dose & Age (Years) & $\begin{array}{l}\text { Drug-Induced } \\
\text { LAD (Y/N) }\end{array}$ & $\begin{array}{c}\text { Time to } \\
\text { Clearance } \\
\text { (yrs/m/w/d) }\end{array}$ & $\begin{array}{l}\text { Relapse } \\
(\mathrm{Y} / \mathrm{N})\end{array}$ & $\begin{array}{c}\text { Side Effects } \\
\text { of } \\
\text { Treatment }\end{array}$ \\
\hline Prednisone [29] & $\begin{array}{l}20 \mathrm{mg} / \mathrm{d} \text { monthly dose } \\
\text { tapering }\end{array}$ & 30 & Unknown & NS & $\mathrm{Y}$ & NS \\
\hline $\begin{array}{c}\text { Dapsone }+ \\
\text { prednisolone } \\
{[28]}\end{array}$ & $\begin{array}{c}\text { Dapsone: } 1-2 \mathrm{mg} / \mathrm{kg} / \mathrm{d} \\
\text { Prednisolone: } 0.5-1 \\
\mathrm{mg} / \mathrm{kg} / \mathrm{d} \text { in tapering } \\
\text { doses }\end{array}$ & $13,9,7,1$ & $\mathrm{~N}$ & $\begin{array}{l}60 \mathrm{~m}, 156 \mathrm{~m}, \\
108 \mathrm{~m}, 24 \mathrm{~m}\end{array}$ & $\mathrm{~N}$ & NS \\
\hline $\begin{array}{c}\text { Oral } \\
\text { corticosteroids } \\
{[30]}\end{array}$ & Unspecified & 8 & NS & $4 \mathrm{~m}$ & NS & NS \\
\hline $\begin{array}{l}\text { Oral } \\
\text { prednisolone }+ \\
\text { corticosteroid } \\
\text { eye drops [25] }\end{array}$ & $0.5 \mathrm{mg} / \mathrm{kg} / \mathrm{d}$ & 7 & NS & $\begin{array}{l}\text { NS, but had } \\
\text { eyelid adhesion } \\
\text { despite clinical } \\
\text { control }\end{array}$ & NS & NS \\
\hline $\begin{array}{c}\text { Dapsone }+ \\
\text { prednisolone }+ \\
\text { cyclosporine } \\
{[16]}\end{array}$ & $\begin{array}{c}\text { Dapsone: } 0.5-2 \mathrm{mg} / \mathrm{kg} \text {; } \\
\text { Prednisolone: } 0.5-1 \mathrm{mg} / \mathrm{kg} \\
\text { Cyclosporine: dose } \\
\text { unspecified }\end{array}$ & 5 & $\mathrm{~N}$ & $\begin{array}{c}\text { NS, but is } \\
\text { well-controlled }\end{array}$ & NS & NS \\
\hline $\begin{array}{c}\text { Topical } \\
\text { triamcinolone }+ \\
\text { vancomycin } \\
\text { cessation [3] }\end{array}$ & $\begin{array}{l}\text { Triamcinolone } 0.1 \% \\
\text { ointment }\end{array}$ & 74 & $\mathrm{Y}$ & $\begin{array}{l}\text { NS, but } \\
\text { clearance was } \\
\text { achieved }\end{array}$ & NS & NS \\
\hline $\begin{array}{l}\text { Topical methyl- } \\
\text { prednisolone + } \\
\text { clobetasol } \\
\text { shampoo [20] }\end{array}$ & $\begin{array}{l}\text { Methylprednisolone: } 0.1 \% \\
\text { BID } \times 8 \mathrm{w}\end{array}$ & 6 & $\mathrm{~N}$ & $5-8 \mathrm{w}$ & $\mathrm{N}$ & NS \\
\hline $\begin{array}{c}\text { Topical } \\
\text { corticosteroids } \\
+ \\
\text { clarithromycin } \\
{[28]}\end{array}$ & $\begin{array}{l}\text { Topical corticosteroids: } \\
\text { mid-potency, unspecified } \\
\text { Clarithromycin: } \\
30 \mathrm{mg} / \mathrm{kg} / \mathrm{d} \text { over } 3 \text { doses } \\
\times 1 \mathrm{~m}\end{array}$ & 5 & $\mathrm{~N}$ & $2.5 \mathrm{~m}$ & $\mathrm{~N}$ & NS \\
\hline $\begin{array}{c}\text { Topical } \\
\text { corticosteroids } \\
{[28]}\end{array}$ & Mid-potency, unspecified & 4 & $\mathrm{~N}$ & $2.5 \mathrm{~m}$ & $\mathrm{~N}$ & NS \\
\hline $\begin{array}{l}\text { Betamethasone } \\
\text { valerate [21] }\end{array}$ & $0.05 \%$ & $4 \mathrm{~d}$ & $\mathrm{~N}$ & $21 \mathrm{~d}$ & NS & NS \\
\hline $\begin{array}{c}\text { Nicotinamide } \\
{[7]}\end{array}$ & $300 \mathrm{mg} / \mathrm{d}$ & $22 \mathrm{~m}$ & $\mathrm{~N}$ & $7 \mathrm{~d}$ & $\mathrm{~N}$ & None \\
\hline $\begin{array}{l}\text { Amoxicillin- } \\
\text { clavulanate } \\
\text { [31] }\end{array}$ & Infusion $\times 7 \mathrm{~d}$ & $7 \mathrm{~d}$ & $\mathrm{~N}$ & $7 \mathrm{~d}$ & $\mathrm{~N}$ & NS \\
\hline
\end{tabular}

\subsubsection{Rituximab}

Rituximab is an anti-CD20 antibody approved by the FDA for pemphigus vulgaris and used off-label for other autoimmune bullous diseases. Four articles cite rituximab as an effective additional agent for severe, recalcitrant LAD. Three of the articles used two 
infusions of $1 \mathrm{~g}$, 2 weeks apart, for two cycles [8,9,12]. One used a dosage of $375 \mathrm{mg} / \mathrm{m}^{2}$ weekly, for a month, with mycophenolate mofetil $500 \mathrm{mg}$ BID (bis in die) after the lack of response to prednisone [11]. In a case with severe ocular involvement, rituximab in combination with IVIg ( $2 \mathrm{~g} / \mathrm{kg} /$ cycle over 3 days, for two cycles) was used [12]. Other sources added rituximab to a regimen of dapsone, prednisone, doxycycline, and MMF due to the lack of response. Time to clearance ranged from 7 weeks to 20 months. Relapses occurred in two out of five patients with LAD, 6 and 9 months after clearance [8,11]. No significant side effects were noted in patients with LAD in any of the articles. However, it may be of benefit for patients to still be clinically followed due to rituximab's immunosuppressive features that place them at greater risk of infections.

\subsubsection{Methotrexate}

One case of LAD associated with chronic ulcerative proctitis resulted in clinical improvement only after the patient's proctitis was treated with methotrexate $(22.5 \mathrm{mg}$ /week) and mesalamine [15]. The patient failed to respond to previous therapy with dapsone, niacinamide, doxycycline, prednisone, intravenous methylprednisolone, topical corticosteroids, and mesalamine monotherapy.

\subsubsection{Sulfonamides}

Sulfamethoxypyridazine and sulfasalazine are sulfonamides that have been reported as effective treatments for LAD, with minimal risk [6,28]. Since dapsone and some sulfa drugs are difficult to obtain in countries such as China, oral sulfasalazine at $40-60 \mathrm{mg} / \mathrm{kg} /$ day was given to a 17-year-old boy in China along with oral sodium bicarbonate to prevent the formation of urinary tract crystals for two months [6]. Another study in Kuwait transitioned a 7-year-old from dapsone to sulfamethoxypyridazine ( $250 \mathrm{mg} /$ day to $1 \mathrm{~g} /$ day for 60 months) because of persistent hemolysis [28]. No relapses or side effects were reported in both patients.

\subsubsection{IVIg}

IVIg is used in immune-mediated diseases, including autoimmune dermatologic conditions. Regarding LAD, three studies used IVIg either as a primary or adjunct treatment if the disease was severe and/or therapy-resistant $[12,19,28]$. The dose used was $2 \mathrm{~g} / \mathrm{kg}$ over a few days, without relapses. Scarpone et al., found that the common side effects of IVIg were headache, abdominal pain, nausea, vomiting, diarrhea, and chest pain in patients with dermatomyositis, vasculitis, vasculopathy, and pemphigus vulgaris. However, no side effects were reported in the patient with LAD. Time to clearance varied from 7 months to 96 months, with a median of 7 cycles.

\subsubsection{Topical Corticosteroids}

Corticosteroids are used in a wide variety of dermatologic conditions. Although not a new treatment for LAD, topical corticosteroids have been popular in the pediatric population for its favorable side effect profile. In a case of uncomplicated CBDC upon delivery with limited mucous membrane involvement, topical treatment with betamethasone valerate $0.05 \%$ at day 4 of life resulted in resolution at day 21 of life [21]. In a 6-year-old female with partial glucose-6-phosphate dehydrogenase deficiency, topical methylprednisolone $0.1 \%$ twice daily (vehicle not specified) and clobetasol shampoo resulted in resolution within a month [20]. In an adult case of vancomycin-induced LAD, vancomycin cessation and triamcinolone $0.1 \%$ ointment alone were enough to resolve bullae [3]. It is unclear as to how long after clinical improvement the patient continued to use topical corticosteroids. Two other cases of mild CBDC showed clinical improvement after 2.5 months of unspecified, mid-potency topical corticosteroid therapy [30]. One of these cases used topical corticosteroids in combination with clarithromycin at $30 \mathrm{mg} / \mathrm{kg} /$ day for 1 month. No cases of topical corticosteroid use reported any side effects. 


\subsubsection{Systemic Corticosteroids}

Systemic corticosteroids were commonly paired with dapsone or IVIg in the treatment of LAD. Prednisolone was used in pediatric patients at a dose of $0.5-1 \mathrm{mg} / \mathrm{kg} /$ day, while prednisolone or prednisone were used at doses of up to $1 \mathrm{mg} / \mathrm{kg} /$ day in adults $[16,19,25,28,29]$. In Nanda et al., prednisolone in tapering doses was added to the dapsone regimen if response was slow. It was also added to IVIg in moderate to severe cases if dapsone was contraindicated. In a severe case of CBDC requiring inpatient admission, a combination of dapsone, prednisolone, and cyclosporine of unspecified dose resulted in a well-controlled disease [16]. The sequence of medication initiation and therefore the role of prednisolone versus cyclosporine is unclear in this case. Another severe case of $C B D C$ required dapsone at $2 \mathrm{mg} / \mathrm{kg} /$ day along with prednisolone and corticosteroid eye drops for treatmentresistant conjunctival involvement [25]. In adults, the use of prednisone alone or in combination with dapsone has resulted in variable success, as reported by Machado et al. Despite high doses of dapsone (100 $\mathrm{mg} /$ day reduced to $50 \mathrm{mg} /$ day due to hemolysis) and prednisone $(1 \mathrm{mg} / \mathrm{kg} /$ day $)$ in one patient, response remained poor. After 5 years of chronic corticosteroid use, she developed Cushingoid facies, arterial hypertension, glaucoma, and osteoporosis. The second patient had the disease completely under control and suspended medication use after 2.5 years of dapsone $(100 \mathrm{mg} /$ day reduced to $50 \mathrm{mg} /$ day due to hemolysis) and prednisone $(0.6 \mathrm{mg} / \mathrm{kg} /$ day $)$. The third patient showed improvement after 1 month of prednisone at $20 \mathrm{mg} /$ day, with relapse after self-initiated cessation of prednisone. Corticosteroids were tapered as clinical improvement was obtained.

\subsubsection{Nicotinamide}

Nicotinamide inhibits inflammatory pathways such as leukocyte chemotaxis, lysosomal enzyme release, mast cell degranulation, and more [7]. There is one article reporting the sole use of nicotinamide to treat CBDC in a 22-month-old Chinese patient. The patient had an 11-day history of lesions after an insect bite, after which nicotinamide at $300 \mathrm{mg} /$ day was initiated. The lesions were completely resolved after 7 days of treatment, without any side effects, and she had no relapses by her 10-month follow-up.

\subsubsection{Amoxicillin-Clavulanate}

One case of neonatal CBDC in a 5-day-old infant without mucosal involvement showed a prompt resolution of the disease after a 7-day amoxicillin-clavulanate infusion of unspecified dose [31]. Amoxicillin-clavulanate was started due to maternal fever and the presence of lesions. However, maternal and neonatal microbiological samples were negative. No relapses were reported after the 20-month follow-up.

\section{Discussion}

The management of LAD has centered around DIF for diagnosis and around dapsone for treatment. Additional diagnostic studies include IIF for IgA anti-basement membrane zone antibodies and H\&E stains showing subepidermal blisters with predominant neutrophils, with or without eosinophils later in the disease process [1]. Repeat biopsy is indicated if clinical suspicion is high in patients with immune dysregulation [3]. Recent literature has shown that serration pattern analysis may be a useful tool for distinguishing between similar presentations such as sublamina densa-type LAD because treatment response will vary depending on the diagnosis [23,24]. In cases of drug-induced LAD, co-incubation with the offending agent has been reported to be helpful in the prevention of false negative IIF results [4]. In addition to IgA, there are cases of IgG and IgM on DIF $[25,26]$. The presence of IgG was associated with ocular involvement and required treatment with both dapsone and corticosteroids in one pediatric case [25]. Due to the small sample size, it is unclear how the presence of multiple antibodies affects clinical management. A wide array of diagnostic testing options should be considered if clinical suspicion is high for LAD. 
There are many different treatment options for LAD, underscoring the challenge of treating this disease with variable clinical presentations and underlying causes. Due to dapsone's side effects, its difficult accessibility in some countries, and the lack of response, other treatments have been utilized. Rituximab and IVIg were typically used for more severe and therapy-resistant cases, while omalizumab was used when there seemed to be a heavy eosinophil involvement. Etanercept was used in vancomycin-induced LAD presenting as TEN, with prompt resolution after one dose. Associated conditions such as ulcerative colitis should be investigated and treated if clinical response to traditional therapy is poor. In the pediatric population where the side effect profile is a priority, sulfonamides, topical corticosteroids, and nicotinamide were preferable. Sulfonamides were used in areas with less access to dapsone, topical corticosteroids were used in newborns and young children, while nicotinamide was used in a toddler. All achieved complete remission without any noted side effects or relapses. Newborns, in particular, should be assessed for precipitating factors that lead to CBDC presentation such as IgA autoantibodies in breast milk, even if mothers are asymptomatic [32]. Many reports did not mention dosage, presence of relapse, side effects, or time to clearance, thus limiting the scope of this review. Another limitation of this review was that "CBDC" was not searched as it was assumed that "linear IgA" would have been a keyword or searchable term in the studies. Although dapsone is most often recommended to patients with LAD, other treatment modalities can be considered based on comorbidities and the response to therapy.

\section{Conclusions}

LAD management has relied on DIF for diagnosis and on dapsone for treatment. A literature search for articles published in the last 5 years has shown that other modalities, including rituximab, omalizumab, etanercept, IVIg, topical corticosteroids, among others have been used successfully in adult and pediatric patients with varying severity of disease. Patient factors such as age, medical comorbidities, and disease severity play a role in therapeutic selection. As in most patient cases in Dermatology where preliminary biopsy results are negative but clinical suspicion is high, a repeat biopsy and additional diagnostic studies should be considered, especially in LAD.

Author Contributions: Conceptualization, H.D.J. and J.T.G.II; methodology, J.T.G.II and L.S.; validation, H.D.J., J.T.G.II and L.S.; formal analysis, J.T.G.II and L.S.; data curation, J.T.G.II and L.S.; writing-original draft preparation, L.S.; writing—review and editing, H.D.J., J.T.G.II and L.S.; supervision, H.D.J.; project administration, H.D.J. All authors have read and agreed to the published version of the manuscript.

Funding: This research received no external funding.

Institutional Review Board Statement: Not applicable.

Informed Consent Statement: Not applicable.

Data Availability Statement: No new data were created or analyzed in this study. Data sharing is not applicable to this article.

Conflicts of Interest: The authors declare no conflict of interest.

\section{References}

1. Bernett, C.N.; Fong, M.; Rosario-Collazo, J.A.; Linear, I.G.A. Dermatosis. [Updated 2021 Jan 15]. In StatPearls [Internet]; StatPearls Publishing: Treasure Island, FL, USA, 2021. Available online: https:/ /www.ncbi.nlm.nih.gov/books/NBK526113/ (accessed on 29 June 2021).

2. Hashimoto, T.; Yamagami, J.; Zone, J.J. History, Diagnosis, Pathogenesis, and Nomenclature in Sublamina Dense-Type Linear IgA Disease. JAMA Dermatol. 2021. [CrossRef]

3. Winn, A.E.; Spillane, E.L.; Peterson, D.J.; Sperling, L.C.; Meyerle, J.H. False-negative direct immunofluorescence testing in vancomycin-induced linear IgA bullous dermatosis: A diagnostic pitfall. J. Cutan. Pathol. 2016, 43, 802-804. [CrossRef]

4. Yamagami, J.; Nakamura, Y.; Nagao, K.; Funakoshi, T.; Takahashi, H.; Tanikawa, A.; Hachiya, T.; Yamamoto, T.; Ishida-Yamamoto, A.; Tanaka, T.; et al. Vancomycin Mediates IgA Autoreactivity in Drug-Induced Linear IgA Bullous Dermatosis. J. Investig. Dermatol. 2018, 138, 1473-1480. [CrossRef] [PubMed] 
5. Vale, E.C.S.D.; Dimatos, O.C.; Porro, A.M.; Santi, C.G. Consensus on the treatment of autoimmune bullous dermatoses: Dermatitis herpetiformis and linear IgA bullous dermatosis-Brazilian Society of Dermatology. An. Bras. Dermatol. 2019, $94,48-55$. [CrossRef]

6. Yang, Z.; Liu, Z.; Sun, C.; Shen, H. Successful treatment of a case of idiopathic linear IgA bullous dermatosis with oral sulfasalazine. Dermatol. Ther. 2020, 33, e13210. [CrossRef]

7. Cui, Y.X.; Yang, B.Q.; Zhou, G.Z.; Zhang, F.R. Childhood linear IgA bullous dermatosis successfully treated with oral nicotinamide. Clin. Exp. Dermatol. 2016, 41, 816-818. [CrossRef] [PubMed]

8. Pinard, C.; Hebert, V.; Lecuyer, M.; Sacre, L.; Joly, P. Linear IgA bullous dermatosis treated with rituximab. JAAD Case Rep. 2019, 5, 124-126. [CrossRef] [PubMed]

9. Islamoğlu, Z.G.K.; Akyürek, F.T. A case of recalcitrant linear IgA bullous dermatosis: Successfully treated with rituximab. Dermatol. Ther. 2019, 32, e12911. [CrossRef]

10. Lamberts, A.; Euverman, H.I.; Terra, J.B.; Jonkman, M.F.; Horváth, B. Effectiveness and Safety of Rituximab in Recalcitrant Pemphigoid Diseases. Front. Immunol. 2018, 9, 248. [CrossRef] [PubMed]

11. Nedosekin, D.; Wilson, K.D.; Campbell, K.; Shalin, S.; Wong, H.K. Immunologic overlap in a case of linear IgG/IgA bullous dermatosis responsive to rituximab. JAAD Case Rep. 2021, 9, 57-60. [CrossRef] [PubMed]

12. Steger, B.; Madhusudan, S.; Kaye, S.B.; Stylianides, A.; Romano, V.; Maqsood, S.E.; Harper, J.; Ahmad, S. Combined Use of Rituximab and Intravenous Immunoglobulin for Severe Autoimmune Cicatricial Conjunctivitis-An Interventional Case Series. Cornea 2016, 35, 1611-1614. [CrossRef]

13. Maalouf, N.S.; Hanna, D. Linear IgA bullous dermatosis successfully treated with omalizumab: A case report. JAAD Case Rep. 2019, 5, 966-969. [CrossRef] [PubMed]

14. Patel, N.H.; Padhiyar, J.K.; Patel, T.D.; Trivedi, N.S.; Chandibhamar, V.S.; Raval, R. A case of linear IgA bullous dermatosis successfully treated with omalizumab. Indian J. Dermatol. 2020, 65, 543-545. [CrossRef]

15. Yetto, T.; Burns, C. Linear IgA bullous dermatosis associated with ulcerative proctitis: Treatment challenge. Derm. Online J. 2018, 24, 14. [CrossRef]

16. Tate, C.; Christian, W.; Newell, L. Chronic Bullous Dermatosis of Childhood and the String of Pearls Sign. J. Pediatr. 2018, 202, 325-325.e1. [CrossRef]

17. Prieto-Barrios, M.; Velasco-Tamariz, V.; Tous-Romero, F.; Burillo-Martinez, S.; Zarco-Olivo, C.; Rodriguez-Peralto, J.; Ortiz-Romero, P. Linear immunoglobulin A dermatosis mimicking toxic epidermal necrolysis: A case report of etanercept treatment. $\mathrm{Br}$. J. Dermatol. 2017, 178, 786-789. [CrossRef]

18. Patsatsi, A.; Lamprou, F.; Kokolios, M.; Stylianidou, D.; Trigoni, A.; Kalampalikis, D.; Sotiriadis, D. Spectrum of Autoimmune Bullous Diseases in Northern Greece. A 4-year Retrospective Study and Review of the Literature. Acta Dermatovenerol. Croat. 2017, 25, 195-201.

19. Scarpone, R.; Meier, K.; Ghoreschi, K.; Worm, M. Intravenous Immunoglobulins in a Series of 32 Rare and Recalcitrant Immune Dermatoses. Acta Derm. Venereol. 2020, 100, adv00298. [CrossRef] [PubMed]

20. Gil Sáenz, F.J.; Urdániz, G.D.; Galar, M.F.; Ballester, J.G.; Varasa, A.H.; Bordege, R.G. Corticoides tópicos como alternativa terapéutica en la dermatosis ampollosa por inmunoglobulina A lineal de la infancia. Caso clínico. Arch. Argent. Pediatr. 2016, 114, e440-e443. [CrossRef]

21. Mazurek, M.T.; Banihani, R.; Wong, J.; Weinstein, M.; Alnutayfi, A.; Etoom, Y. Uncomplicated Neonatal Linear IgA Bullous Dermatosis: A Case Report. J. Cutan. Med. Surg. 2018, 22, 431-434. [CrossRef]

22. Fulton, E.; Jan, F.; Zimarowski, M.J. Flame figures in linear IgA bullous dermatosis: A novel histopathologic finding. Dermatol. Online J. 2017, 23, 17. [CrossRef]

23. Shetty, V.M.; Pai, S.B.; Rao, R. Linear IgA bullous dermatosis presenting as chronic prurigo: Unveiling of the diagnosis by serrated pattern analysis. Int. J. Dermatol. 2018, 57, e147-e149. [CrossRef]

24. Becker, M.; Schumacher, N.; Schmidt, E.; Zillikens, D.; Sadik, C.D. Evaluation and Comparison of Clinical and Laboratory Characterstics of Patients With IgA Epidermolysis Bullosa Acquisita, Linear IgA Bullous Dermatosis, and IgG Epidermolysis Bullosa Acquisita. JAMA Dermatol. 2021. [CrossRef]

25. Fernandes, K.D.A.P.; Galvis, K.H.; Gomes, A.C.D.M.S.; Nogueira, O.M.; Felix, P.A.O.; Vargas, T.J.D.S. Linear IgA and IgG bullous dermatosis. An. Bras. Dermatol. 2016, 91 (Suppl. 1), 32-34. [CrossRef]

26. Lim, G.H.; Cai, S.C.S.; Lee, J.S.S.; Chen, Q. Rare case of linear IgA bullous dermatosis showing $\operatorname{IgA}$, $\operatorname{IgG}$ and $\operatorname{IgM}$ reactivity. Australas. J. Dermatol. 2021, 62, e361-e362. [CrossRef] [PubMed]

27. Ohata, C.; Ishii, N.; Koga, H.; Nakama, T. A clinical and serological study of linear IgA bullous dermatosis without linear immunoglobulin deposition other than IgA at the basement membrane zone using direct immunofluorescence. Br. J. Dermatol. 2016, 177, 152-157. [CrossRef]

28. Nanda, A.; Lazarevic, V.; Rajy, J.M.; Almasry, I.M.; AlSabah, H.; AlLafi, A. Spectrum of autoimmune bullous diseases among children in Kuwait. Pediatr. Dermatol. 2020, 38, 50-57. [CrossRef] [PubMed]

29. Machado, T.Y.S.; Enokihara, M.M.S.E.S.; Iida, T.M.; Porro, A.M. Adult linear IgA bullous dermatosis: Report of three cases. An. Bras. Dermatol. 2018, 93, 435-437. [CrossRef] [PubMed]

30. Varo, R.; Fernández-Luis, S.; Sitoe, A.; Bassat, Q. Suspected case of chronic bullous disease of childhood in a rural area of Southern Mozambique. BMJ Case Rep. 2017, 2017, bcr2016218315. [CrossRef] 
31. Giraud, L.; Welfringer-Morin, A.; Boccara, O.; Frassati-Biaggi, A.; Leclerc-Mercier, S.; Grootenboer-Mignot, S.; Bodemer, C.; Hadj-Rabia, S. Neonatal and self-healing linear immunoglobulin A dermatosis. J. Eur. Acad. Dermatol. Venereol. 2019, 34, e86-e87. [CrossRef]

32. Egami, S.; Suzuki, C.; Kurihara, Y.; Yamagami, J.; Kubo, A.; Funakoshi, T.; Nishie, W.; Matsumura, K.; Matsushima, T.; Kawaida M.; et al. Neonatal Linear IgA Bullous Dermatosis Mediated by Breast Milk-Borne Maternal IgA. JAMA Dermatol. 2021. [CrossRef] [PubMed] 